\title{
Competitive recovery of the small business sector through understanding its role and essence: regional aspects
}

\author{
Vitaliy Yurievich Burov \\ Transbaikal State University \\ Faculty of Economics and management \\ Chita, Russia \\ burovschool1956@yandex.ru
}

\author{
Georgiy Leonidovich Bagiev \\ Saint Petersburg State University \\ Saint Petersburg, Russia
}

\author{
Zhargal Bairovna Tumunbayarova \\ Faculty of Economics and management \\ Chita, Russia \\ Transbaikal State University
}

\begin{abstract}
The article considers some problems concerned with efficiency of state regulation and small business (SB) support in Russia taking into account the change of its essence and role, including the issues at the regional level.

Currently in Russia and abroad, theoretical insights devoted to SB essence have a certain specificity aimed mainly at underlining some positive aspects of small business.

But modern realities prove the need to review the theoretical insights in the aftermath of the radical transformation of Russian economy, which occurred in recent years and caused an increase in shadow economic activity of small enterprises. At the same time, the domestic economy ceased to be closed one and gradually became an integral part of the global economy. The fact predetermines the further development of Russian economy based on digital technologies, being an important factor for regional economy.

It is also necessary to emphasize that, despite the variety of the theoretical problems raised within the study of SB theory, there is a lack of attention paid to its essence transformation in the context of shadow activity of small enterprises. Also, speaking about applied researches, inadequate share of attention is paid to the methods of state influence on shadow activity of small businesses that is connected directly with delegation of authorities and responsibilities to regional and municipal levels during state support implementation.
\end{abstract}

Keywords - small business, shadow economic activity, economic essence, state regulation, digital economy

\section{INTRODUCTION}

Historically, the state has a significant role in economic processes in Russia. It is an open secret that the improvement of the state regulation system and small business (SB) support rests upon scientific and methodological base.
Although the study of small business growth and its problems is quite deep, there is a deficit in scientific theoretical and practical developments which are aimed at the analysis of essence and fairly clear understanding of place and role of small business in the modern market economic model as an independent economic sector. It hampers clear formulation of the concepts of SB state regulation and countering shadow economic activity taking into account regional characteristics.

The significant influence on understanding of modern small business nature was rendered by works of such foreign authors as J. Schumpeter, J. Kirschner, F. Hayek, R. Coase, F. Knight, O. Williamson, E. Chamberlin, J. Galbraith, etc.

So, S. Shane (2003) considers entrepreneurship to be a key mechanism in acceleration of economic development and draws our attention to its ability to provide employment opportunities and, at the same time, to increase per capita income. He also emphasizes that many business representatives are self-employed population by their nature, and they see income from business as a substitute for their wages.

W. Baumol calls attention to the role of institutions and associates it with informal relationships. He notes that if you run a business with the help of organic growth based on innovations, and to do it is more difficult for you than to imply various "bribe" forms for unfriendly takeovers, recovery of political rents, etc., entrepreneurial potential of society will take an appropriate configuration.

Works of domestic scientists such as A.O. Blinov, E.M. Buhvald, M.G. Lapust, A. V. Orlov, A. Yu. Chepurenko, etc., are devoted to the state regulation of small business and its role in the Russian economy. 
Thus, A. Yu. Chepurenko (2012) notes, "In particular, criticize the idea that small business is a provider of employment opportunities and it is necessary to support any startups". As it turns out, it is not always that this idea is fair. There are some industries, which are, by definition, more suitable for large business development, and employment opportunities provided by startup companies in great numbers, also disappear in the same quantity due to the high "mortality" rate of micro and small businesses. "

From a scientific point of view, shadow economy study has appeared in global practice rather recently, since 1930s. And rightly so, domestic science is based mainly on Western concepts and theories. The analysis of functional characteristics, development of shadow economy and preliminary estimation of their scale in planned economy are described in the works of G. Grossman A. Kaliberda T. Koryagina, D. Kaufman, L. Schneider, and so on.

According to E. Feige (1990), the main factor determining the success of the creation and functioning of an effective market economy is the degree of coherence among formal and informal norms: their incoherence causes strong incentive for illegal economy. Besides, G. Yamada mentions that informal economic activity is a result of voluntary choice of people who try to receive higher income.

In the context of the prevailing political, economic and, in some cases, social situations, the necessity of sustainable socio-economic territorial development proves the urgency of improvement of state regulation effectiveness over small businesses, being an important strategic resource for the development of both the country as a whole and the regions in particular.

The authors' researches confirm that in order to compensate for the negative environmental impact, small businesses are reorienting their activities into the shadow sector of the economy. It leads to an increase in the scope of shadow economic activity (SEA), being a dominant in the volume of small business activities and reaching, according to different data, up to $50 \%$ of the economic activity volume and up to $85 \%$ of hidden wages in Russia. (V. Burov, 2012).

\section{MATERials And Methods (Model)}

The validity of the research results is proved by the use of works of Russian and foreign scientists, whose studies are devoted to theoretical questions of the essence of small business, its place in the economy, SB state regulation development, shadow economy and its counteraction, and development of digital economy.

The methodological basis of the work is represented by dialectical and comparative methods of scientific knowledge, as well as by methodology of a number of fundamental and applied scientific disciplines of economic theory and entrepreneurship.

In the course of the research the authors used the following modern methods of scientific analysis of economic processes:

-System approach in order to study the SB sector both as a system and as a subsystem of the country's economy; a system analysis of state regulation of the small business sector and approaches to the state SEA counteraction among SB subjects;

- general-to-specific approach - small business essence analysis in the context of SEA and its role in economic development of the country within unstable environment;

-Economic and statistical approach - to analyze and assess the development level and potential of small business, dividing small enterprises into manufacturing businesses, capable to implement digital innovations, and non-productive ones, having destructive influence on the digital economy development.

\section{RESULTS AND DISCUSSION}

It should be noted that, despite the variety of theoretical problems raised in the study of small business theory, insufficient attention is paid to the role of small business in the development of regional economies. Also, if to speak about applied researches, there is a lack of attention paid to both methods of state influence on shadow activity of small enterprises and stimulation of digital technologies implementation among small businesses:

- The existing definitions of "small business" are based on classical theory and do not take into account the modern institutional environment, as well as the role of small enterprises in the development of the digital economy;

- The approaches applied to the analysis of the small business functions and SB significance reduce the depth of researches and do not allow to reveal the dualism of the small business phenomenon in modern context at the regional level;

- the existing approaches to the state regulation and support of small business system do not correspond to modern tendencies and realities - the works do not take into account the following fact: there is a dependence of economic activity of small enterprises on specific limited territories connected with local markets;

- while carrying out theoretical researches, the importance of state and public institutions in counteraction to SEA in the small business system is not fully taken into account. It should be done with main focus on regions.

It is hard to escape the conclusion that small business in Russia carries out its activity and tries to develop in the teeth of negative external conditions caused by ineffective state support of SB. At the same time, the potential of small enterprises is not fully used, and it has a negative effect on competitiveness, sustainability, and development security of regional economic systems. 


\section{CONCLUSION}

On the basis of the revealed problems in formation and development of technologies, especially in the official sector of the economy, it is possible to conclude that not every entrepreneur has an opportunity to realize his business successfully. It is connected with instability of economy and policy, unequal competition, resource access problem, high taxes, as well as entrepreneurs' incompetence in business matters and their lack of economic knowledge as a whole.

The first, it causes a necessity of changing the approach to definition of small business that will allow to perform its classification.

The second, it requires a new approach to the consideration of small business functions and their importance. It will reveal the dualism of such a phenomenon as small business in the modern context: under the conditions of imperfect institutional environment, it can be seen as a driver for innovative (digital) economy development, in one respect, and, in the other respect, it can have a destructive impact on the process in case of non-productive SB. Functional destructiveness of a small enterprise is revealed in the fact that non-productive SB subjects become a decelerator for economic development, as they are not ready to perform their economic activity with the use of digital technologies.

The third, there is a need to change approaches to government regulation and support of the small business system, as the existing regulatory system does not meet current trends and realities. During the formation of state regulation systems at the present stage, the necessity of decentralization of state policy concerning development and support of SB is not taken into account. Today the policy is based on the attachment of small enterprises to local resources, local markets, and limited territory of economic activity;

The fourth, it is necessary to take further into account the significance of state and public counteraction to shadow economic activity in the small business subsystem, due to the concentration of huge resources in the shadow sector of economy.

The fifth, without denying the importance of the state role in the development of small business, it is necessary to assess the role of society in strengthening the importance of small business in the formation of the digital economy. A result is always a mutual process, so it is impossible to expect a positive outcome without an adequate reaction and actions on the part of society. Therefore, theoretical studies in this direction will give an opportunity to formulate specific provisions that can be implemented in practice.

The problems solved within the framework of this article provide a fundamental change in the quality of small business essence study that will allow to improve approaches to the state regulation and support of small business sector in Russia in the context of digital technologies development and counteraction to their shadow economic activity. 


\section{References}

[1] S. A. Shane, General Theory of Entrepreneurship: The IndividualOpportunity Nexus, Cheltenham, UK: Edward Elgar, 2003.

[2] W. J. Baumol, "Entrepreneurship in Economic Theory," American Economic Review, 1968, vol. 58, no. 2, pp. $64-71$.
[3] A. Yu. Chepurenko, "What is Entrepreneurship and What Entrepreneurship Policy Does Russia Need? (Margin Notes on Works of Modern Foreign Classics),"[Chto takoe predprinimatel'stvo i kakaja politika v otnoshenii predprinimatel'stva nuzhna Rossii? (Zametki na poljah rabot sovremennyh zarubezhnyh klassikov)], The Journal of the New Economic Association [ZhurnalNovoj jekonomicheskoj associacii], no.2(14), Moscow . pp. $102-124$. 